\title{
RISK AWARENESS AND SEXUAL RELATIONSHIPS AMONG YOUTH IN THE JOHANNESBURG AREA
}

\author{
FG Netswera \\ MPhil (Social Sciences Methods) \\ Senior Researcher, Technikon SA \\ Correspondence: gnetswer@tsa.ac.za
}

Keywords: sexual stability; risk awareness; sexual relationships

\begin{abstract}
The increase in the reported rate of the human immunodeficiency virus (HIV), acquired immune deficiency syndrome (AIDS) and sexually transmitted infections among the youth of South Africa has led to a rise in awareness campaigns to combat these epidemics. If health awareness campaigns have an effect on behavioural change, one would expect the youth to abstain from sex and be involved in stable sexual relationships. This quantitative survey, conducted among a sample of 226 Johannesburg youths, was aimed at ascertaining their exposure to sex risks and their stability in sexual relationships. Data was collected by means of a questionnaire, and descriptive as well as inferential statistical analyses were computed using the Statistical Package for Social Sciences (SPSS). The results revealed a quarter of respondents to have been engaged in risky sexual activities and males in general to be riskier and more sexually active than women.
\end{abstract}

\section{OPSOMMING}

Die toename in die aangemelde koers van menslike immuniteitsgebreksindroom (MIV), verworwe immuniteitsgebreksindroom (VIGS) en seksueel oordraagbare infeksies onder die jeug in Suid-Afrika het tot 'n toename in bewuswordingsveldtogte gelei om hierdie epidemie hok te slaan. Indien gesondheidsveldtogte ' $n$ effek op gedragsverandering het, kan 'n mens verwag dat die jeug hulself van seksuele omgang sal weerhou en in stabiele seksuele verhoudings betrokke sal wees. 'n Kwantitatiewe opname is onder 226 jeugdiges in Johannesburg gedoen met die doel om hul blootstelling aan seksuele risiko's en stabiele seksuele verhoudings te bepaal. Data-insameling het deur middel van 'n vraelys geskied en beide beskrywende en inferensiële statistiese analise is deur middel van die Statistical Package for Social Sciences (SPSS) gedoen. Die resultate het aangetoon dat 'n kwart van die respondente in riskante seksuele aktiwiteite betrokke was en mans was oor die algemeen waaghalsiger en seksueel meer aktief as vroue. 


\section{BACKGROUND}

In 1997 approximately 1,8 million people were already infected with HIV and more than 700 new infections were reported to be occurring daily in South Africa (South Africa, 1997:108). HIV/AIDS in South Africa has affected young men and women more than it has affected any other age cohort (National Youth Commission, 1997). The Annual National Antenatal Clinic Survey (ANACS) for the period 1995 to 1999 indicated the highest prevalence of HIV/AIDS to be among women aged between 20 and 29 years (Williams, Gouws, Colvin, Sitas, Ramjee \& Abdool, 2000:307). For the period 1997 and after, the highest rates of infection were observed among women younger than 20 years $(65,4 \%$ ) (Alder \& Qulo in Hennis, Van Rensburg \& Ngwena, 2000:54). The annual HIV infections for 2000 were estimated as follows: KwaZulu-Natal 36,2\%, Mpumalanga 29,7\%, Gauteng 29,4\%, Free State 27,9\%, North-West 22,9\%, Eastern Cape 20,2\%, Northern Province 13,2\%, Northern Cape 11,2\% and Western Cape 8,7\% (South Africa, 2000).

The above figures indicate only the registered HIV infections, and it is acknowledged that many more unregistered infections exist and are increasing at a rapid rate. The infection figures are highest among the sexually active population, which comprises mainly youth. Reported statistics are as follows: $29,1 \%$ in the age group 20-24 years, 30,6\% in the age group 25-29 years and $23,3 \%$ in the age group $30-34$ years. South Africa (2000) revealed significant HIV infection increase among pregnant women between 1998, 1999 and 2000 to be highest in Gauteng $(22,5 \%-23,9 \%$ $29,4 \%)$ followed by KwaZulu-Natal (32,5\% - 32,5\% $36,2 \%)$. Interestingly, these figures are highest amongst the youth, especially the age groups 20-24 (29,0\%), 25-29 (30,6\%) and 30-34 (23,3\%).

In his study, Peltzer (2000:37) found that there is still ignorance and a lack of risk awareness among the youth, specifically among females (30\%), who are insufficiently aware that condoms offer protection against HIV/AIDS and sexually transmitted infections. The spread of HIV/AIDS is on the increase, particularly among the sexually active members of the population, with an AIDS prevalence rate expected to reach $27 \%$ by the year 2010. It is for this reason that one of the objectives of the National AIDS Control Programme is to prevent the spread of the epidemic by promoting safer sexual behaviour, ensuring adequate provision of condoms and controlling sexually transmitted infections (South Africa, 1999). There is a strong correlation between the prevalence of HIV and sexually transmitted infections such as syphilis among age groups and provinces. The syphilis prevalence rate, as recorded by the South African demographic and health survey (SADHS), from a population of 16575 countrywide in 2000 , is the highest amongst the age group 25-29 (5,4\%), followed by $20-25(4,9 \%)$ and 30 $34(4,5 \%)$. Unmarried women are found to have the highest number of sexual partners, while only $8 \%$ of the survey sample (12247) had used condoms in these relationships.

\section{PROBLEM STATEMENT}

Given the high HIV infection rate indicated in this background, it is obvious that South Africa faces an enormous problem if an HIV/AIDS cure is not immediately found or a change in sexual attitudes and behaviours is not fostered. South Africa will be robbed of millions of its population, especially the youth and young adults, as prevalence is highest amongst these groups. The effects of these epidemics will be seriously felt in skill shortages, the general economic growth and performance and growth rate of orphanages. It is for this reason that the Ministry of Health, non-governmental organisations and other media such as radio and televisions have held several campaigns to alert South Africans of the importance of abstinence from unprotected sexual activities. Whether or not these campaigns have had an effect on the sexual practices by youths can only be ascertained through their sexual attitudes and behaviours, including the change in trends on infection rates.

\section{OBJECTIVES}

The objectives of this research are to:

- explore how susceptible youth are to the risky sexual practices that could lead to sexually transmitted infections and/or possible death

- describe the sexual behaviours and tendencies of youth in their respective sexual relationships 


\section{CONCEPT CLARITY}

Youth: Refers to the age category of 14 to 35, which, according to the South African youth policy, comprises $39 \%$ of the South African population (National Youth Commission, 1997).

Risk awareness: Refers to the conscious awareness that one can be prone to the health hazards posed by unsafe sexual practices, which includes multiple sexual partners and unprotected sex.

Sexual relationships: Relationships in which the involved partners practise sex, including oral, anal and vaginal sexual intercourse as defined in the Oxford Dictionary (1992:835).

\section{THEORETICAL FRAMEWORK}

The Health Belief Model (HBM) as described by Frewen, Schomer and Dunne (1994) assumes that the behaviour or decision-making may be predicted from the value of the outcome of an action and from the expectation that the action will prevent or ameliorate the health problem. In this case, youth's behaviour is expected to be modelled on informed decisions knowing that they are susceptible to sexually transmitted diseases and unwanted pregnancies. The likelihood of the stated problems would be associated with certain outcomes and therefore inform the attitudes towards such behaviour.

\section{LITERATURE}

Socio-economic factors such as migration and widespread population displacement are cited to be conditions that enable the spread of HIV and significantly increase women's risk of contracting the virus. Poor economies in the frontline states compel many young and sexually active men to seek employment in South Africa (Reid, 1995:55). With spouses left in their homelands, most find themselves engaged in prostitution and other risky sexual behaviour.

The media, which includes television and movies, have a major influence on the sexual behaviour of youth, leading to spontaneous and often unprotected sexual activities. Among the youth there is a lack of under- standing and knowledge of bodily functioning and proper sexual counselling and guidance, coupled with the desire to explore sex. This leads not only to pregnancy but also to sexually transmitted diseases. Statements and comments like "I did not think it could happen to me the first time around" are often made by youth who are caught unguarded (Siphepho \& Gmeiner, 2000:29). Changing the sexual behaviour of the youth is one of South Africa's greatest developmental challenges - one that it shares with other countries that also have a high AIDS infection rate.

Teen pregnancy and single parenting seem to have become more acceptable among communities recently. This is assumed to be another cause of unprotected sexual activity by youth, where having a baby is perceived as a tangible accomplishment. Only onethird of the teenage couples expecting a baby chose marriage in $1987,42 \%$ of pregnancies ended in abortion and only $4 \%$ of the unmarried teenagers put their babies up for adoption (Williams \& Mavundla, 1999:61). Thus a different perception of teenage pregnancy and its consequences were portrayed in 1987 from more accommodating attitudes found in 1999 in the RSA. The latter perception portraying a baby as a "tangible accomplishment" could impact negatively both on teenagers' use of contraceptives and on their commitments to engage in "safe sex".

Deviation from cultural norms and practices and the dependency on economic activity have seen family structures shrinking. Abstinence from sexual activity, which was previously guided by cultural practices, is slowly fading away. A pregnant teen now adds a burden to most families and the young mother has to fend for both herself and her children. In the first half of the twentieth century, society condemned unmarried pregnant teenagers, but since then this condemnation has given way to acceptance and even approbation (O'Neill \& Leone, 1994:52-53).

In poverty-stricken and broken families, the sexual behaviour of the parents, who are a source of income for the family, is an influence on the youth. The young grow up ignorant about sexuality. At one extreme are parents who oppose any form of instruction or discussion related to sexuality, and at the other extreme are those who are ready for extensive education in the 
schools providing contraceptives. It is argued that the latter encourages mischievous sexual behaviour and the former encourages ignorant behaviour (Berlfein, 1992:61).

The consequences of HIV/AIDS and sexually transmitted infections are felt throughout the world, and as a result the World Health Organisation (WHO) is fully involved in campaigns and activities to combat these. Because of this pandemic, the World Health Organisation determined that a minimum health expenditure rate of $5 \%$ of all countries' gross domestic product (GNP), as an international criterion, should be allocated for the provision of acceptable health care standards.

Blaxter (1996:33) has commented on the disappointing features of the United Kingdom's national health services and community care reforms, which reflect a lack of real discussion of the relevance of the social determinants of health. An overwhelming focus on health care organisations - and by implication on a medical model of health - obscured the equally important environmental, behavioural and biological determinants of health (Jones, 1994:12-13).

\section{RESEARCH DESIGN}

This exploratory and descriptive study made use of a quantitative research design (Babbie \& Mouton, 2001). The research was contextually bound geographically, and a research questionnaire was administered to youth residing in Johannesburg.

\section{Population and sample}

The study population was youth in the Johannesburg city centre. The sample consisted of 226 youths, who were selected using a non-probabilistic purposive sampling method (Bless \& Higson-Smith, 2000). It was non-probabilistic because not just any individual could participate in this study. Prospective participants, once approached, were asked two main questions, which determined their inclusion and participation in the study - firstly their age, in order to confine participation to youths, and secondly their area of residence, in order to include only Johannesburg youth (Babbie \& Mouton, 2001).

\section{Data collection instrumentation}

An interview schedule/questionnaire was developed as a data collection instrument to collect two types of information:

- Section I: Biographical data (9 items)

- Section II: Sexual behaviour/attitude and health awareness (33 Likert scale items - see tables 1 and 2)

Section II of the administered questionnaire consisted of 33 items presented in a 5-point Likert scale, where 1 = strongly disagree, 2 = disagree, $3=$ uncertain, $4=$ agree and $5=$ strongly agree. According to De Vaus (1991:290), the use of extended scales, such as fivepoint or seven-point scales and above, produces "lazy forms of analysis". The scale was therefore collapsed from a five-point into a three-point scale, in which the original 1 and 2 became "disagree", 4 and 5 became "agree" and 3 remained "uncertain" (Alreck \& Settle, 1985:133). The reliability test for the two behavioural scales was computed in SPSS as 0.6049 for sexual stability, with a variance of 0.0219 ; and for health awareness 0.7449 , with a variance of 0.0215 .

\section{Validity and reliability}

The development of the questionnaire relied on two main aspects:

- Information collected from literature

- A group discussion was held between the two researchers, one of who happened to be a former nurse, and two lecturers from the Health Sciences department of the Technikon Southern Africa. The group was provided with a draft questionnaire, which was then reviewed question per question until all were satisfied that it was free of bias and all other possible errors.

Group discussion of the questionnaire enabled its validity and reliability to be ensured. Thorough discussions focused on the appropriateness of questions, and, for the purpose of objectivity, the drafted questionnaire was given to two researchers who were not part of the study, for checks of reliability and validity (Peterson, 2000). A test-retest method was used by 
piloting the questionnaire to ten youths to ensure that the language level was appropriate and that the terminology was easy to understand. Some questions were reconstructed, some removed and some added as a result of the suggestions of both independent researchers and the pilot youth group.

\section{Data collection}

Two research assistants who were conversant with fieldwork activities were responsible for data collection. Fieldworkers moved into and around the Johannesburg city centre for five consecutive days, where they identified and approached youthful passers-by. These potential respondents were briefed about the research and informed that only people from Johannesburg and under the age of 35 could participate. Fieldworkers sat down on the pavements with willing respondents to complete the questionnaire. Literate respondents filled in the questionnaire themselves, with clarification being given where required. Illiterate respondents responded orally to questions read to them directly from the questionnaire by the fieldworkers, who then captured the responses. The fieldworkers' general understanding of most African/indigenous languages became important during this phase of the study (Babbie \& Mouton, 2001:249).

\section{Ethical considerations}

Owing to the fieldwork setting, some respondents refused to participate for various reasons, which included lack of interest, being in a hurry and the researcher's inability to understand the respondent's language. Respondents who indicated an interest in participating gave verbal consent, and their anonymity was ensured as their names and any other information that could trace them was not captured. Respondents were also made to understand that they were not compelled to answer questions that they did not feel comfortable answering.

\section{Data analysis}

Collected data was captured in the American Standard Code for Information Interchange (ASCII) file and read into SPSS editor. Open-ended questions and comments were post-coded and captured as numeric data (Babbie \& Mouton, 2001:481-484). Data analysis techniques used included the Chi-square and analysis of variance (ANOVA).

\section{Realisation of the sample}

The realised survey sample ( $N=226)$ comprised $53,5 \%$ males and $46,5 \%$ females. The age categories were as follows: $33 \%$ between 15 and 19 years, $38 \%$ between 20 and 23 years, $18 \%$ between 24 and 27 years and $11 \%$ between 28 and 32 years. ( $M$ of age $=21$ years.) Concerning marital status, the majority were single $(85,8 \%)$, followed by unmarried couples living together $(6,2 \%)$, married couples $(5,3 \%)$, divorcees $(1,8 \%)$ and those who had been widowed $(0,9 \%)$. The residential areas from which respondents came were mainly the major townships in and around Johannesburg - there were 155 from Soweto $(69,3 \%), 20$ from the Johannesburg suburban areas $(4,0 \%), 11$ from Duduza (4,9\%), 9 from Alexandra (4,0\%) and 2 from Thembisa $(0,9 \%)$.

Concerning educational qualifications, the majority of respondents had matriculated $(36,6 \%)$, followed by high school students $(34,4 \%)$, those with "other" certificates $(12,6 \%)$, undergraduate students $(12,0 \%)$ and postgraduate students $(4,5 \%)$.

The majority of the respondents were students who were not working $(42,7 \%)$, followed by the unemployed $(21,4 \%)$, full-time workers $(18,6 \%)$ and students who were working $(17,3 \%)$.

More than two-thirds $(71,9 \%)$ of all respondents were non-parents, $74 \%$ of who were involved in a committed sexual relationship. Respondents who had more than two partners comprised $21,3 \%$, those involved in casual relationships comprised $3,2 \%$ and homosexuals comprised $1,4 \%$. Casual sexual relationship was a post-coded variable not included in the questionnaire; it emerged during fieldwork, being defined by some respondents as "sexual relationships that are on an 'on-off' basis and lack emotional intimacy and commitment".

\section{Sexual relationships}

The assessment of stability in sexual relationships 
through 16 Likert scale items revealed the following results:

Individual item observations revealed only minimal disparities between males and females in respect of sexual stability. Differences in attitude noted among males and females, although minimal, exist in their degree of "contentment" with current sexual relationships. There is reluctance by males to marry their current partners, having "eyes" on other individuals instead. The idea of "having eyes" on someone could be misleading if thought to imply mischievous intentions. However, it actually refers to the likelihood that such an individual can and might "go out with/date" others. There is little or no commitment on the part of most males to keep the current sexual relationship going. Behavioural similarities between males and females include jealousy or possessiveness (item 12). According to the results, this is prevalent among males (see table 1).

Table 1: Sexual relationships $(\mathrm{N}=226)$

\begin{tabular}{|c|c|c|c|c|}
\hline & $\begin{array}{l}\text { M a le } \\
(N=12\end{array}$ & & $\begin{array}{l}\text { Fem a Ic } \\
(N=10\end{array}$ & \\
\hline & Agree \% & Disagree \% & Agree \% & Disagree \% \\
\hline 1. I am prepared to marry $m$ y current partner & 12,1 & 18,7 & 18,7 & 11,1 \\
\hline $\begin{array}{l}\text { 2. I would nevertell } m \text { y friends about m y } \\
\text { current partner }\end{array}$ & 6,9 & 3,0 & 4,2 & 35,2 \\
\hline $\begin{array}{l}\text { 3. I am shy to introduce } m \text { y partner to } m y \\
\text { friends }\end{array}$ & 4,6 & 41,9 & 1,8 & 42,4 \\
\hline $\begin{array}{l}\text { 4. I have eyes on someone else apart from my } \\
\text { currentpartner }\end{array}$ & 25,2 & 23,4 & 8,4 & 33,6 \\
\hline $\begin{array}{l}\text { 5. I will keep m y current partneruntil I get } \\
\text { anotherone }\end{array}$ & 17,0 & 16,5 & 14,2 & 18,9 \\
\hline $\begin{array}{l}\text { 6. I am sure that I will leave m y current partner } \\
\text { soon }\end{array}$ & 7,9 & 24,3 & 5,1 & 28,5 \\
\hline 7. I enjoy proposing love to total strangers & 18,8 & 30,0 & 2,8 & 39,0 \\
\hline $\begin{array}{l}\text { 8. I intend introducing/have introduced } m y \\
\text { current partner to } m y \text { fam ily }\end{array}$ & 30,0 & 14,0 & 26,1 & 7,7 \\
\hline 9. I do not trust m y current partner & 13,6 & 25,4 & 9,9 & 27,7 \\
\hline 10. I mayend my relationship anytime now & 7,0 & 26,8 & 3,8 & 31,5 \\
\hline $\begin{array}{l}\text { 11. I would considersuicide if } m \text { y partner were to } \\
\text { leave me }\end{array}$ & 4,7 & 42,2 & 5,2 & 32,2 \\
\hline $\begin{array}{l}\text { 12. If I talk to otherguys/ladies, my partnergets } \\
\text { jealous }\end{array}$ & 20,0 & 20,5 & 20,0 & 16,7 \\
\hline $\begin{array}{l}\text { 13. If } \mathrm{m} \text { y partner/l should becom e pregnant, I will } \\
\text { m arry him /her }\end{array}$ & 12,1 & 31,5 & 3,0 & 19,4 \\
\hline $\begin{array}{l}\text { 14. My partnerdoes not pay maintenance fee for } \\
\mathrm{his} / \mathrm{her} b a b y\end{array}$ & 9,8 & 35,9 & 4,6 & 38,6 \\
\hline
\end{tabular}




\section{Computing scale variables}

SPSS procedures allow for the creation of a second $(0$ to $100 \%$ ) scale variable from a pool of items that are meant to measure the same phenomenon, e.g. sexual stability. The two second variables computed from the 3-point Likert scale questions are sexual stability and health awareness, derived from a pool of 16 and 17 items, respectively. Items that were phrased negatively were assigned reversed numbers to allow for the same direction for all items (Babbie \& Mouton, 2001: 412414). The computation formula is as follows:

$$
Y=(\operatorname{var} 1+\operatorname{var} 2 \ldots / n)^{*}(100 / y-1)-(100 / y-1)
$$

Where:

$$
\begin{aligned}
& \mathrm{Y}=\text { target variable } \\
& \mathrm{V}=\text { individual Likert items } \\
& \mathrm{N}=\text { number of variable items added } \\
& \mathrm{y}=\text { scale (either } .3 \text { or } .7, \text { etc.) }
\end{aligned}
$$

The new scale variables, namely stability and health awareness, were recoded to scores of between $0 \%$ and $100 \%$, with $0 \%$ to $49 \%$ representing an insatiable sexual appetite and sexual unawareness, and $50 \%$ to $100 \%$ representing stability and awareness.

\section{Scale-based findings}

The results of the T-test indicated that there is no statistically significant difference between men and women in the sexual stability category $(p=0.05)$. Stability in sexual relationships is therefore neither dependent on nor influenced by the gender of the respondents. The same test also revealed that health awareness is not dependent on the gender of the individual.

To ascertain whether persons with different educational backgrounds, parenting status and marital status differ statistically in terms of sexual stability, a one-way analysis of variance (ANOVA) was computed. There were significant differences between persons with and without children (Chi-square $=16.46, \mathrm{df}=21, \mathrm{p}=0.05$ ), and between persons of different marital status (Chisquare $=52.874, d f=63, p=0.05)$. A one-way analysis of variance, however, indicated that there is no statistically significant difference in terms of health awareness between groups of persons with different gender, employment status and marital status and those with and without children.

\section{Risk awareness}

Although the inferential tests computed and discussed above show no differences in the behaviour of individuals in the various categories, analysis of individual score items reveals that there are certain divergent tendencies, although minimal, which are reflected in table 2. For example, risk-taking tendencies by males are reflected in "having slept with total strangers and other individuals outside the relationship" and the perception that "making love to a new person is interesting". Other risk-inclined thoughts, which would not necessarily result in actual risky behaviour, include considering "sleeping" with famous people and celebrities and seeking satisfaction elsewhere if sexually dissatisfied with the current partner. In a similar study conducted among Ugandan students, Lule and Gruer (in Peltzer, 2000:38) found that only a minority saw condom use as an effective preventive method against HIV/ AIDS infection. In the same study condoms were found to be used by $35 \%$ males, while most saw the use of condoms as encouraging promiscuity.

Although not in their majority, numerous respondents prefer to remain clueless about their HIV/AIDS status amidst the campaigns to reveal status by the infected to deter the non-infected from behaviour such as "sleeping around". This can be attributed to their risk-taking behaviour, particularly males, many of whom are afraid of taking the HIV test because they have slept outside their current relationships.

\section{LIMITATIONS}

Although a mixture of purposive and convenience sampling was used, it was coupled with little cross-racial group coverage. The lack of racial representation has the following shortcoming: the inability of this research to provide racial comparisons of the analysed behaviour.

Owing to lack of funds for the study, the researcher incurred enormous costs in travel and printing of ques 
Table 2: Risk awareness ( $\mathrm{N}=\mathbf{2 2 6}$ )

\begin{tabular}{|c|c|c|c|c|}
\hline & \multicolumn{2}{|c|}{$\begin{array}{l}\text { Male } \\
(\mathrm{N}=121)\end{array}$} & \multicolumn{2}{|c|}{$\begin{array}{l}\text { Female } \\
(\mathrm{N}=105)\end{array}$} \\
\hline & Agree \% & Disagree \% & Agree \% & Disagree \% \\
\hline 1. My current partner is my first sexual partner & 11,7 & 38,3 & 18,2 & 24,3 \\
\hline 2. I am afraid of contracting HIV/AIDS & 45,1 & 4,7 & 34,4 & 6,5 \\
\hline 3. I do not make sex/sleep with my partner at all & 9,3 & 41,7 & 8,3 & 36,1 \\
\hline $\begin{array}{l}\text { 4. I enjoy making sex/sleeping with different } \\
\text { people }\end{array}$ & 19,4 & 29,6 & 2,8 & 38,0 \\
\hline $\begin{array}{l}\text { 5. If dissatisfied sexually with my partner, I } \\
\text { would consider satisfaction somewhere else }\end{array}$ & 17,0 & 26,4 & 7,4 & 34,0 \\
\hline 6. I have slept with a total stranger before & 20,4 & 27,3 & 3,7 & 40,3 \\
\hline 7. It is interesting making love to a new person & 30,8 & 13,1 & 9,8 & 26,2 \\
\hline 8. I will only start having sex when I get married & 6,6 & 37,0 & 9,0 & 31,8 \\
\hline $\begin{array}{l}\text { 9. I would consider having sex with any good- } \\
\text { looking person (e.g. TV personality) }\end{array}$ & 17,2 & 27,7 & 4,2 & 38,1 \\
\hline $\begin{array}{l}\text { 10. I have slept with another person outside this } \\
\text { relationship }\end{array}$ & 23,9 & 25,4 & 9,4 & 33,8 \\
\hline 11. I don't enjoy using condoms at all & 17,8 & 26,6 & 14,0 & 23,8 \\
\hline $\begin{array}{l}\text { 12. I have contracted a sexually transmitted } \\
\text { disease before }\end{array}$ & 9,6 & 39,4 & 6,7 & 35,6 \\
\hline 13. I will never consider being tested for HIV & 14,3 & 26,7 & 9,0 & 29,0 \\
\hline $\begin{array}{l}\text { 14. I am afraid that I may currently be HIV } \\
\text { positive }\end{array}$ & 14,6 & 24,1 & 12,7 & 22,2 \\
\hline $\begin{array}{l}\text { 15. I would prefer not knowing that I am HIV } \\
\text { positive than to know }\end{array}$ & 17,0 & 26,4 & 15,1 & 21,2 \\
\hline 16. If my partner uses condoms, I don't enjoy sex & 14,4 & 27,2 & 11,9 & 26,2 \\
\hline
\end{tabular}


tionnaires and thus the study was limited to a sample size of 226, which renders it less generalisable to the youth of Gauteng.

\section{RECOMMENDATIONS}

This research has revealed certain sexual tendencies in youth behaviour that may be regarded as risky. To combat such behaviour, the following recommendations are important:

\section{Sexuality education}

The provision of sexuality education to youth needs to be approached in a positive and holistic manner that bridges the gap between the scientific and popular perspectives. Guidance and counselling should not be provided solely by hospitals to families and academic institutions. Where cultural barriers still exist and parents cannot communicate with their children about sexuality, certain interventions need to be developed and implemented.

Cultural tendencies have enabled men to engage in several sexual relationships, including marriage to several women. With changing times and socio-economic demands, behaviour that was culturally regarded as "macho" should be discouraged and young males should be reoriented to currently suitable behaviours and educated to behave in less risky ways.

\section{Health campaigns}

Since most youth are influenced mainly by movies and television, as found by Siphepho and Gmeiner (2000:29), it could be beneficial to use television stars and popular role models to communicate the importance of the fight against the spread of HIV/AIDS.

\section{Further research}

After analysing the data of this study, it became clear that the following needs to be further explored:

Owing to the lack of benchmark studies, results with regard to behavioural change cannot easily be compared with previous studies. Time-series studies that monitor groups of individuals over time are needed to determine the ongoing effect of sexuality education on relationships and awareness.

The study recommends the development of a sex education programme for youth, the implementation of which can be evaluated through an experimental study, and which will enable behaviour change to be ascertained by comparing youth who are exposed to the education with those who are not.

\section{CONCLUSIONS}

There is an urgent need to intensify the campaign and fight against HIV/AIDS infection through sexuality education and to uproot the ignorance of the youth regarding the hazards of unprotected sex. Youth's susceptibility to risky sexual practices poses a potential danger to their future as individuals and to the future of the country as a whole, which depends upon them.

\section{REFERENCES}

Alreck, PL \& Settle, RB 1985: The survey research handbook. Homewood, III: Irwin.

Babbie, E \& Mouton, J 2001: The practice of social research. South African edition. Cape Town: Oxford.

Berlfein, J 1992: Teen pregnancy. San Diego: Lucent Books.

Blaxter, M 1996: Health and social organisation. London: Routledge. Bless, C \& Higson-Smith, C 2000: Fundamentals of social research methods - An African perspective; 3rd edition. Kenwyn: Juta.

De Vaus, DA 1991: Surveys in social research; 3rd edition. London: UCL.

Frewen, S; Schomer, H \& Dunne, T 1994: Health Belief Model: interpretation of compliance factors as a weight loss and cardiac rehabilitation programme. South African Journal of Psychology, 24(1):39-43.

Hennis, C; Van Rensburg, D \& Ngwena, C 2000: A "Youth Multifunction Centre" in the Free State: An alternative to clinic-based HIV/AIDS prevention and Care. Curationis, 4(23):54-62.

Jones, LJ 1994: The social context of health and health work. London: MacMillan.

National Youth Commission 1997: National youth policy. Pretoria: Government Printer.

O’Neill, T \& Leone, B 1994: Teenage sexuality: opposing viewpoints. San Diego: Greenhaven.

Oxford Dictionary 1992: The Oxford dictionary of current English. New York: Oxford University Press.

Peltzer, K 2000: Factors affecting condom use among junior sec- 
ondary school pupils in South Africa. Health SA Gesondheid, 5(2):37-44.

Peterson, RA 2000: Constructing effective questionnaires. Thousand Oaks: Sage.

Reid, E 1995: HIV and AIDS - The global interconnection. West Hartford: Kumarian.

Siphepho, JS \& Gmeiner, AC 2000: The promotion of mental health of adolescents in a township in Swaziland. Curationis, 1(23):2535.

South Africa. Department of Health 1997: White paper on the transformation of the health system in South Africa. Pretoria: Government Printer.

South Africa. Department of Health 1999: South African Demographic and Health Survey (SADHS), 1998/1999. Pretoria: Government Printer.

South Africa. Department of Health 2000: National HIV and Syphilis Sero-Prevalence Survey. Pretoria: Government Printer.

Williams, CX \& Mavundla, TR 1999: Teenage mothers' knowledge of sex education in a general hospital of the Umtata district. Curationis, 1(22):58-63.

Williams, GB; Gouws, E; Colvin, M; Sitas, F; Ramjee, G \& Abdool, K 2000: Patterns of infection: Using age prevalence data to understand the epidemic of HIV in South Africa. South African Journal of Science, 96(June):305-312. 